\title{
FACTORES QUE INFLUENCIAN EL ACCESO A LA EXTENSIÓN AGROPECUARIA EN PERÚ: BUSCANDO MODELOS MÁS INCLUSIVOS
}

\author{
FACTORS THAT INFLUENCE ACCESS TO AGRICULTURAL AND LIVESTOCK EXTENSION IN \\ PERU : IN SEARCH FOR MORE INCLUSIVE MODELS
}

\author{
Christian Barrantes-Bravo $^{1^{*}}$, Jesús Salinas-Flores ${ }^{1}$, J. Luis Yagüe-Blanco $^{2}$
}

\begin{abstract}
${ }^{1}$ Universidad Nacional Agraria La Molina. Avenida La Universidad S/N La Molina. Lima 18. Perú. (chbarrante@lamolina.edu.pe) (jsalinas@lamolina.edu.pe). ${ }^{2}$ Universidad Politécnica de Madrid. Calle Ramiro de Maeztu, 7. 28040. Madrid, España. (joseluis.yague@upm.es)
\end{abstract}

\section{RESUMEN}

Con la finalidad de evaluar el acceso a los servicios de extensión en el Perú, luego de los procesos de privatización y descentralización por los que pasó, se realizó un análisis de los resultados del Censo Nacional Agropecuario de 2012, empleando además un método multivariado (algoritmo de árbol de clasificación - CHAID), con la finalidad de establecer el perfil de los productores que reciben servicios de extensión en función de diferentes variables predictivas. Se encontró que $\mathbf{1 0 . 2} \%$ de los productores agropecuarios del país accede a servicios de extensión y que el ofertante más importante de tales servicios es el sector privado. Se determinó que la superficie agrícola mayor a $5 \mathrm{ha}$, el asociacionismo y el acceso al crédito son los factores más relacionados con el acceso a la extensión, evidenciándose, en el perfil del productor que recibe extensión, su vinculación con la agricultura comercial. Se concluye que los cambios suscitados en la extensión en el Perú no han logrado mejorar el acceso a los mismos, sobre todo a nivel de los pequeños productores, verificándose también la necesidad de un cambio de enfoque que, fortaleciendo a los nuevos actores y usando modelos más flexibles, la vuelvan cada vez más inclusiva.

Palabras clave: agricultura comercial, asistencia técnica, descentralización, pequeños agricultores, privatización.

\section{INTRODUCCIÓN}

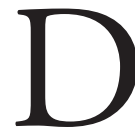
esde hace varios años se ha cuestionado a los servicios de extensión agrícola públicos, debido a sus pobres resultados y altos costos. Las mayores críticas a los sistemas de extensión públicos están ligadas a su propia eficiencia, motivadas por

* Autor responsable * Author for correspondence.

Recibido: enero, 2015. Aprobado: diciembre, 2015.

Publicado como ARTÍCULO en ASyD 14: 205-217. 2017.

\section{AbSTRACT}

With the aim of evaluating the access to extension services in Peru, after the processes of privatization and decentralization which the country underwent, an analysis of the results of the National Agricultural and Livestock Census from 2012 was performed, using also a multivariate method (algorithm of classification tree - CHAID), with the objective of determining the profile of the producers who receive extension services in function of different predictive variables. It was found that $10.2 \%$ of the agricultural and livestock producers in the country have access to extension services and that the most important provider of such services is the private sector. It was determined that an agricultural surface larger than $\mathbf{5}$ ha, associationism, and access to credit are the factors most frequently related with access to extension services, showing in the profile of the producer who receives extension work its connection to commercial agriculture. It is concluded that the changes stirred up by extension work in Peru have not managed to improve access to them, particularly at the level of small-scale producers, and also verifying with this the need for a change in approach which, strengthening new actors and using more flexible models, make it increasingly more inclusive.

Key words: commercial agriculture, technical assistance, decentralization, small-scale farmers, privatization.

\section{INTRODUCTION}

The public agricultural extension services have been questioned since several years ago, due to their poor results and high costs. The greatest criticism to the public extension systems are linked to their own efficiency, motivated by state bureaucracy and the lack of motivation of public officials; in addition, the use of participative approaches is rarely 
la burocracia estatal y la falta de motivación de los servidores públicos; además, el uso de enfoques participativos rara vez se ajusta bien a las competencias organizacionales del sector público o de las estrategias individuales de los agentes de la administración pública (Kidd et al., 2000).

Una revisión de 2001 patrocinada por la Organización de las Naciones Unidas para la Agricultura y la Alimentación Naciones (FAO), por ejemplo, caracteriza a los servicios de extensión en todo el mundo en desarrollo como defectuosos, moribundos y en desorden ( Rivera et al., 2001, citado por Feder et al., 2010).

Se han configurado así nuevas propuestas para la mejora de los servicios de extensión, basados en la participación del sector privado, partiendo de la hipótesis de que la posibilidad de realizar acuerdos público-privados para proveerlos, así como el uso de fondos públicos, pero manejados por un sistema privado incrementaría la eficiencia del sistema y la cobertura para llegar a todos los grupos de agricultores (Dethier y Effenberger, 2012).

En algunos lugares de Europa, incluso el nombre del servicio de extensión ha sido cambiado por el de asesorías pluralistas. Detrás de este cambio semántico, el cual se puede encontrar en muchos países tales como Francia, Inglaterra, Holanda y Alemania, se muestra el rol creciente de los actores privados (Labarthe y Laurent, 2013). Para ser eficaces, los proveedores de servicios de extensión deben colaborar con empresas, bancos, organizaciones no gubernamentales y con otros prestadores de servicios (McMahon y Valdés, 2011).

Sin embargo, se debe notar que este nuevo enfoque constituye un cambio radical y que, por lo tanto, su aplicación genera ciertas dificultades. El paso de una prolongada tradición de servicios públicos -según la cual estos servicios se han recibido sin costo alguno para los productores y los técnicos han desempeñado sus funciones sin desarrollar una actitud empresarial- a una nueva situación en la cual productores y extensionistas deben desenvolverse en un mercado de servicios, requiere de fuertes incentivos para su consecución (Mora, 2002).

Esto coincide con la necesidad de que los agricultores interioricen su quehacer como un negocio, en el cual la asesoría y la innovación tienen un costo. Los agricultores comerciales requerirán entrenamiento en gestión empresarial y asesorías que les ayudarán a escalar en la well-adjusted to the organizational competencies of the public sector or to the individual strategies of the public administration agents (Kidd et al., 2000).

A 2001 review financed by the Food and Agriculture Organization of the United Nations (FAO), for example, characterizes extension services in the entire developing world as faulty, dying and in disarray (Rivera et al., 2001, citado por Feder et al., 2010).

Thus, new proposals have been configured for the improvement of extension services, based on the participation of the private sector, stemming from the hypothesis that the possibility of establishing public-private agreements to provide them, as well as the use of public funds, although managed by a private system, would increase the efficiency of the system and the coverage to reach all groups of farmers (Dethier and Effenberger, 2012).

In some places of Europe, even the name of extension service has been changed for that of pluralist consultancies. Behind this semantic change, which can be found in many countries such as France, England, Holland and Germany, the growing role of private actors is shown (Labarthe and Laurent, 2013). To be efficient, the providers of extension services must collaborate with businesses, banks, non-governmental organizations, and other service providers (McMahon and Valdés, 2011).

However, it must be noted that this new approach constitutes a radical change and that, therefore, its application generates certain difficulties. The step from a prolonged tradition of public services according to which these services have been received without any cost to the producers, and the technicians have performed their functions without developing an entrepreneurial attitude- to a new situation in which producers and extension workers must manage in a service market, require strong incentives for their attainment (Mora, 2002).

This agrees with the need for farmers to internalize their work as a business, in which consultancy and innovation have a cost. The commercial farmers will require training in entrepreneurial management and consultancies that will help them climb in the value chain, while small-scale farmers will require technique, both as market and financial information, and as assistance to go from subsistence production to a commercial type of enterprise (Pye-Smith, 2012). 
cadena de valor, mientras que los pequeños agricultores requerirán técnica, tanto como información de mercado y financiera, y asistencia para pasar desde la producción para la subsistencia, a un tipo comercial de empresa (Pye-Smith, 2012).

Un primer efecto de la privatización de los servicios se observa sobre el flujo de la información pues transformándose de un bien público a uno privado, el flujo tiende a reducirse. Si un agricultor tiene que pagar al servicio de extensión por el conocimiento que ha aprendido, este estará menos inclinado a compartir el conocimiento con otros agricultores que cuando estaba disponible gratuitamente (Van den Ban y Samanta, 2006).

Por otro lado, la privatización afecta el contenido de los servicios que se ponen a disposición pues estará cada vez más identificado con las necesidades de las medianas y grandes explotaciones que serán los que pagarán más fácilmente por los servicios. Si la tendencia actual continúa es probable que el servicio de extensión cada vez sea menos relevante para las pequeñas explotaciones (Labarthe y Laurent, 2013).

Otro aspecto a resaltar en los nuevos enfoques de extensión es el planteamiento de una extensión más descentralizada y cercana al terreno. Los servicios de extensión centralizados han mostrado siempre una dificultad respecto a su pertinencia, debido a su pobre capacidad de contextualizar la problemática local, sobre todo de los pequeños agricultores; por otro lado, la supervisión de los servicios bajo este sistema no ha sido posible, por lo que se considera que mientras más local sea planteado el servicio, será más efectivo y controlable.

Sin embargo, la efectividad de la descentralización también depende de los enfoques y objetivos de la misma. Existen reportes sobre la descentralización de los servicios de extensión realizada en China, indicando que las mismas han generado que los técnicos de la extensión gasten mucho más tiempo en trámites administrativos que en extensión efectiva, debido a que los mandatos de los gobiernos locales son, sobre todo, crecimiento económico y estabilidad social (Hu et al., 2012).

$\mathrm{Si}$ analizamos el recorrido de la agricultura en Latinoamérica podremos ver que todos los países han pasado por experiencias, en sentido general, similares. Más allá de sus singularidades, en América Latina y El Caribe existen rasgos comunes que provienen de una misma tradición agraria: heterogeneidad estructural,
A first effect of the privatization of services is observed on the flow of information since the flow tends to decrease when changing from a public to a private good. If a farmer has to pay the extension service for the knowledge he has attained, he will be less inclined to share the knowledge with other farmers than when it was freely available (Van den Ban and Samanta, 2006).

On the other hand, privatization affects the content of the services that are made available, for it will be increasingly more identified with the needs of medium-scale and large-scale farms which will be the ones to pay for the services more easily. If the current trend continues, it is likely that the extension service is increasingly less relevant for small-scale farms (Labarthe and Laurent, 2013).

Another aspect to highlight in the new approaches to extension is the suggestion of a more decentralized extension work and closer to the land. The centralized extension services have always shown a difficulty with regards to their pertinence, due to their poor capacity of contextualizing the local problematic, particularly of small-scale farmers; on the other hand, the supervision of services under this system has not been possible, so it is considered that the more local the service is set out, the more effective and controllable it will be.

However, the effectiveness of the decentralization also depends on its approaches and objectives. There are reports about decentralization of extension services carried out in China, indicating that they have generated for extension technicians to spend much more time in administrative negotiations than in effective extension, because the mandates of local governments are, above all, economic growth and social stability (Hu et al., 2012).

If we analyze the path of agriculture in Latin America we can see that every country has undergone similar experiences, in a general sense. Beyond their singularities, in Latin America and the Caribbean there are common features that come from the same agrarian tradition: structural heterogeneity, incomplete technological modernization, low population density, great availability of natural resources, institutional weakness, community tradition, low endowment of social capital, and high inequality in land distribution, among others (Sotomayor et al., 2011).

In the early 1980s, Latin American countries were experiencing an important crisis provoked by the 
modernización tecnológica incompleta, baja densidad de población, gran disponibilidad de recursos naturales, debilidad institucional, tradición comunitaria, baja dotación de capital social y alta desigualdad en la distribución de la tierra, entre otros (Sotomayor et al., 2011)

A inicios de 1980, los países de Latinoamérica vivían una crisis importante provocada por la política de sustitución de importaciones y de regulación de precios. Por esto, con algunos años de diferencia entre cada país, tuvieron que asumir medidas de ajuste estructural. Estas se reflejaron en la reducción del tamaño del Estado y de sus mecanismos de intervención en la economía; en el debilitamiento de las instituciones prestadoras de servicios públicos, así como la desregulación de los mercados (Birbaumer, 2011).

Todos estos cambios afectaron directamente a la extensión agrícola pública, la cual se presenta como un gasto sin grandes resultados, y se propone la reducción de los servicios por parte del Estado. Durante años se observa una reducción del personal público dedicado a la extensión, dejando un vacío que fue cubierto por las organizaciones no gubernamentales financiadas por la cooperación internacional.

Con el nuevo siglo y las perspectivas positivas de la agricultura en América Latina resurge el interés por los servicios de extensión. Por ejemplo, el Informe de Desarrollo Mundial de 2008 hace hincapié en la extensión agrícola como una intervención importante para el desarrollo de los países en dos vertientes: 1) para potenciar el crecimiento del sector agrícola, a la luz del aumento de la demanda y las presiones de la oferta; y 2) para promover el desarrollo sostenible (Raabe, 2008; citado por Cuevas et al., 2012).

Ho y Montero (2014) indican que las nuevas iniciativas de los servicios de extensión en Latinoamérica combinan los siguientes esquemas: i) el desarrollo de un mercado de servicios dentro del ámbito privado, en sectores de la gran y mediana agricultura comercial; ii) una modalidad con cierto nivel de subsidio según la cual el Estado transfiere recursos a empresas privadas y organizaciones no gubernamentales para la provisión de servicios a la pequeña agricultura comercial, dentro de programas especiales; y iii) una modalidad para la agricultura de subsistencia en el marco de programas públicos de desarrollo rural o programas de lucha contra la pobreza.

Estas modalidades propuestas son las que hacen decir a Alemany (2008) que la privatización de la policy of import substitution and price regulation. Therefore, with some years of difference between each country, they had to implement structural adjustment measures. These are reflected in the reduction of the size of the State and of their mechanisms of intervention in the economy; in the weakness of the institutions that provide public services, as well as in the deregulation of markets (Birbaumer, 2011).

All these changes directly affected the public agricultural extension, which is presented as an expense without great results, and the reduction of services by the State is proposed. During years a reduction of the public staff devoted to extension is observed, leaving a void that was covered by the nongovernmental organizations financed by international cooperation.

With the new century and the positive perspectives of agriculture in Latin America the interest for extension services resurges. For example, the Global Development Report of 2008 emphasizes agricultural extension as an important intervention for the development of countries in two aspects: 1) to potentiate the growth of the agricultural sector, in light of the increase in demand and the pressures of the offer; and 2) to promote sustainable development (Raabe, 2008; cited by Cuevas et al., 2012).

Ho and Montero (2014) indicate that the new initiatives of the extension services in Latin America combine the following schemes: i) the development of a market of services within the private sphere, in sectors of large-scale and mediumscale commercial agriculture; ii) a modality with a certain level of subsidy according to which the State transfers resources to private companies and nongovernmental organizations for the provision of services to small-scale commercial agriculture, within special programs; and iii) a modality for subsistence agriculture within the framework of public programs for rural development or programs for the fight against poverty.

These modalities suggested are the ones that make Alemany (2008) say that privatization of rural extension has its conceptual bases in the view that "viable" agriculture is already industrialized and integrated in a subordinate manner to the agrifood chains, while the "non-viable" or the "residue resistant to modernization" is a problem that should be tackled as a social problematic, not a productive one and of growth. 
extensión rural tiene sus fundamentos conceptuales en la visión que la agricultura "viable" está ya industrializada e integrada subordinadamente a las cadenas agroalimentarias, mientras que la "no viable" o el "residuo resistente a la modernización” es un problema que debe ser abordado como una problemática social, no productiva y de crecimiento.

Los actuales diseños y políticas de extensión hacen también énfasis en la descentralización en Perú, Chile, Brasil, México, traspasando financiamiento y decisiones a nivel regional o local, permitiendo que el proceso de toma de decisiones sea más cercano a los usuarios. Sin embargo, no queda claro que este proceso vaya suficientemente acompańado por el fortalecimiento de las capacidades en esos niveles que permita asegurar la calidad y sostenibilidad de la extensión (Aguirre, 2012).

Como podemos observar, queda aún mucho por evaluar de estos cambios en los servicios de extensión en América Latina para verificar la problemática que conlleva su aplicación. Al respecto, Swanson (2010) indica que la experiencia en América Latina y en otras regiones demuestra que reemplazar estos sistemas públicos de extensión por empresas del sector privado o por organizaciones no gubernamentales probablemente cause otra serie de problemas y limitaciones que pueden reducir aún más el éxito de estos métodos alternativos.

Hellin (2012) indica además que en la mayoría de los casos, el sector privado se ha mostrado incapaz de reemplazar los servicios que antes realizaba el sector público, debido a los altos costos de transacción, la dispersión de la clientela y el bajo (o no existente) beneficio, situación que se vuelve más evidente frente a los pequeños productores.

Los servicios de extensión agraria en el Perú han seguido procesos paralelos a los ocurridos en toda América Latina (Ho y Montero, 2014), ya que fueron afectadas por políticas similares. Las políticas agrícolas en el Perú se dirigieron a reducir los subsidios, la promoción del libre comercio y la participación del sector privado en la investigación y provisión de información (Ortiz, 2006); esto motivó que los organismos no gubernamentales asuman un rol importante en la oferta de servicios de extensión, actividad que se vio mermada a medida que los fondos de Cooperación Internacional se fueron reduciendo.

Todos estos cambios evidentemente no obedecían solo a un contexto externo que impulsaba este cambio,
The current designs and policies of extension also emphasize decentralization in Peru, Chile, Brazil, and México, transferring funding and decisions to the regional or local level, allowing for the process of decision making to be closer to the users. However, it is not clear that this process will be sufficiently accompanied by the strengthening of the capacities at these levels which allow ensuring the quality and sustainability of extension work (Aguirre, 2012).

As we can see, there is still much to evaluate regarding these changes in extension services in Latin America to verify the problematic that its application entails. In this regard, Swanson (2010) indicates that the experience in Latin America and in other regions proves that replacing these public extension systems with private sector companies or with nongovernmental organizations will probably cause another series of problems and limitations that could reduce even further the success of these alternative methods.

Hellin (2012) indicates in addition that in most cases, the private sector has been proven incapable of replacing the services that the public sector formerly performed, due to the high transaction costs, the dispersion of the clientele, and the low (or nonexistent) benefits, situation that becomes increasingly more evident in face of the small-scale producers.

The agrarian extension services in Peru have followed processes parallel to those that took place in all of Latin America (Ho and Montero, 2014), since they were affected by similar policies. The agricultural policies in Peru were directed at reducing the subsidies, the promotion of free trade and the participation of the private sector in research and information provision (Ortiz, 2006); this motivated for non-governmental organizations to assume an important role in the offer of extension services, activity that was lessened as International Cooperation funds decreased.

All these changes evidently did not obey only an external context that drove this change, but also the recognition of a very serious problem in the services offered by the State. According to Carrasco (1990), in 1990 the situation of agricultural extension was the following: 203 rural development centers in the country, 1301 people devoted to extension, with very little equipment for their mobility, who had not developed activities in the field since years ago, and only in some localities had the support of producers 
sino también al reconocimiento de un problema muy serio en los servicios ofrecidos por el Estado. Según Carrasco (1990), en 1990 la situación de la extensión agrícola era la siguiente: 203 centros de desarrollo rural en el país, 1301 personas dedicadas a la extensión, con muy poco equipamiento para su movilidad, los cuales no desarrollaban actividades en el campo desde hacía años, y solo en algunas localidades contaban con apoyo de productores para acciones esporádicas. En general, los servicios se encontraban paralizados y el personal empobrecido, desmoralizado y desactualizado.

Luego de la aplicación de las medidas de ajuste, la situación cambió radicalmente. Por ejemplo, el programa gubernamental de extensión agrícola conducido por lo que ahora es el Instituto Nacional de Innovación Agraria (INIA) empleaba 1400 agentes en 1986, pero el personal se redujo hasta menos de 100 agentes en 1992 (Hellin y Dixon, 2008).

Por otro lado, se promueven las grandes inversiones agrícolas para favorecer el desarrollo de la agroexportación. Así, el interés en el pequeño productor por parte del Estado se redujo a favor de un interés mayor en la expansión de la inversión de grandes capitales privados en el agro (Remy y De los Ríos, 2012). Según Eguren (2006), los campesinos que mantienen una agricultura de subsistencia han sido marginados de toda pretensión de desarrollo y se los ha convertido en objeto de los llamados "programas sociales".

Esta situación provocó que los organismos no gubernamentales intentaran cubrir el vacío dejado por el Estado a través de proyectos financiados por la cooperación internacional. Según Ramírez y Roe (2007), las organizaciones no gubernamentales impulsaron un sinnúmero de consorcios, alianzas y convenios bilaterales para apoyarse en la implementación de actividades de extensión y difusión tecnológica. Sin embargo, a pesar de que muchas Organizaciones no gubernamentales hacían planteamientos participativos, para Wiener (2010) su enfoque seguía siendo de oferta.

A partir de 2001 las políticas de descentralización en el Perú permitieron que los gobiernos regionales y locales tengan la posibilidad de impulsar el desarrollo agrícola; por otro lado, el gobierno nacional generó una serie de programas que han buscado crear un mercado de servicios de extensión, siendo el más importante de ellos el Programa de Fomento de la Innovación Tecnológica y la Competitividad en la Agricultura del Perú (INCAGRO). for occasional actions. In general, the services were paralyzed and the staff impoverished, demoralized and outdated.

After the application of the adjustment measures, the situation changed radically. For example, the government program of agricultural extension led by what is now the National Agrarian Innovation Institute (Instituto Nacional de Innovación Agraria, INIA) employed 1400 agents in 1986, but the staff was reduced to less than 100 agents in 1992 (Hellin and Dixon, 2008).

On the other hand, large agricultural investments are promoted to favor the development of agroexports. Thus, the interest in small-scale farmers by the State was reduced in favor of a greater interest in the expansion of the investment of large private capitals in agriculture (Remy and De los Ríos, 2012). According to Eguren (2006), peasants who maintain subsistence agriculture have been marginalized from all ambition of development and they have been made into the object of the so-called "social programs".

This situation caused for non-governmental organizations to attempt to cover the void left by the State through projects financed by international cooperation. According to Ramírez and Roe (2007), non-governmental organizations promoted countless consortiums, alliances and bilateral agreements to be supported in the implementation of activities of extension and technological diffusion. However, although many non-governmental organizations made participative suggestions, for Wiener (2010), their approach continued to be offering.

Since 2001 the decentralization policies in Peru allowed for regional and local governments to have the possibility of promoting agricultural development; on the other hand, the national government generated a series of programs that have sought to create a market of extension services, with the most important one being the Program for Technological Innovation and Competitiveness Promotion in Peru's Agriculture (Programa de Fomento de la Innovación Tecnológica y la Competitividad en la Agricultura del Perú, INCAGRO).

For the World Bank (2012), INCAGRO seems to have been a good investment and a successful project, although equality continues to be a preoccupation: most beneficiaries of this program were mediumscale and large-scale farmers, instead of the most disadvantaged producers, including women., Some 
Para World Bank (2012), INCAGRO parece haber sido una buena inversión y un proyecto exitoso, pero la equidad seguía siendo una preocupación: los mayores beneficiarios de este programa fueron los medianos y grandes productores, en lugar de los productores más desfavorecidos, incluidas las mujeres. En su segunda fase, se realizaron algunos cambios para contrarrestar esta situación, pero se indica que los resultados no han sido claros.

Posteriormente han surgido en el Perú nuevos programas nacionales que han manejado el mismo enfoque, por lo cual se vuelve muy importante conocer si estos alcanzan realmente a los pequeńos productores (que constituyen la realidad más importante de la agricultura en el Perú y en muchos países de Latinoamérica) o, en todo caso, comprender cuáles son las características de aquellos productores que sí son alcanzados por estos servicios, de tal manera de promover los cambios necesarios para ampliar el acceso.

En este sentido, el caso del Perú, que ha pasado en los últimos 25 años por ambos procesos (privatización y descentralización), es una realidad interesante para investigar sus efectos en la prestación de servicios de extensión, principalmente a nivel del acceso y de la tipología de productores que alcanzan tales servicios.

Es objetivo de este trabajo determinar, a partir del análisis de los datos del Censo Nacional Agropecuario realizado en el Perú (INEI, 2013), el nivel de cobertura de los servicios de extensión en el Perú y sus proveedores principales, así como identificar los principales factores que influyen en el acceso de los servicios de extensión, a partir del análisis del perfil de los productores que reciben estos servicios.

\section{Materiales y Métodos}

Se tomó la información referente al Censo Nacional Agropecuario, realizado en el Perú en 2012. La información fue catalogada para determinar la cobertura de los servicios de extensión (especificados como asistencia técnica, capacitación o asesoría empresarial en los resultados censales) y las entidades que realizaron dichos servicios; analiza tal cobertura en función de la superficie agrícola del productor y el tipo de entidad que provee el servicio.

Por otro lado, de toda la información sobre los productores contenida en el censo se seleccionaron changes were implemented in its second phase to counteract this situation, but it is indicated that the results have not been clear.

Later new national programs have emerged in Peru which have had the same approach, so it becomes quite important to understand whether these actually reach the small-scale farmers (which constitute the most important reality of agriculture in Peru and in many countries of Latin America), or, in any case, to understand which are the characteristics of those producers who are reached by these services, in order to promote the necessary changes to broaden the access.

In this sense, the case of Peru, which has undergone both processes (privatization and decentralization) in the last 25 years, is an interesting reality to research their effects on the provision of extension services, primarily at the level of access and the typology of producers who are reached by such services.

The objective of this study is to determine, based on the analysis of data from the National Agricultural and Livestock Census carried out in Peru (INI, 2013), the level of coverage of extension services in Peru and their main providers, as well as to identify the principal factors that influence the access to extension services, from the analysis of the profile of the producers who receive these services.

\section{Materials ANd Methods}

Information referring to the National Agricultural and Livestock Census carried out in Peru during 2012 was taken. The information was cataloged to determine the coverage of the extension services (specified as technical assistance, training or entrepreneurial consultancy in the census results), and the entities that performed these services; this coverage is analyzed in function of the agricultural surface of the producer and the type of entity that provides the service.

On the other hand, of all the information about the producers contained in the census, the most important predicting variables were selected in function of the relationship there is between extension work and some socioeconomic characteristics of the producers. The ones selected were: size of agricultural/livestock unit, agricultural surface, age and sex of the producer, legal condition, associationism, level of literacy, level of education, use of agricultural machinery, access 
las variables predictoras más importantes en función de la relación existente entre la extensión y algunas características socioeconómicas de los productores. Las elegidas fueron: tamaño de unidad agropecuaria, superficie agrícola, edad y sexo del productor, condición jurídica, asociacionismo, nivel de alfabetismo, nivel de educación, uso de maquinaria agrícola, acceso al crédito, distancia a la capital del distrito, acceso a programas sociales, percepción de la suficiencia de su nivel de ingresos, entre otras.

Para determinar las características de los grupos de productores que reciben servicios de extensión se aplicó el algoritmo de árbol de clasificación CHAID (Chi-squared Automatic Interaction Detection), el cual es un método de análisis multivariado que mediante una técnica de análisis de segmentación de variables (explicadas y explicativas) permite establecer relaciones de dependencia entre las mismas (Escobar, 2007), con estas variables se formaron árboles de respuestas basados en las frecuencias relativas en sus relaciones. Se estableció como restricción del sistema que los grupos tengan al menos $50 \%$ de productores que logran acceder a los servicios de extensión agrícola. Para el procesamiento de los datos se utilizó el software estadístico IBM Statistics, versión 20.

Luego de obtener los resultados para los servicios de extensión en general se realizó el mismo análisis para los servicios de extensión agrícola ofertados por cada institución proveedora, sea esta pública o priva$\mathrm{da}$, con la finalidad de determinar si alguna de ellas tenía una población objetivo característica o se focalizaba en alguna tipología de productor agropecuario.

\section{Resultados y Discusión}

En el Cuadro 1 se muestra la cobertura de los servicios de extensión en el Perú en función del tamaño del productor agropecuario. En él se puede observar que la cobertura para todo el país es de $10.2 \%$ del total de productores, con una tendencia hacia la baja en función del menor tamaño de unidad agropecuaria, superficie; esto estaría indicando en forma inicial que los cambios en el enfoque de los servicios no han logrado tener eficacia respecto a la provisión de servicios de extensión para los pequeños productores, sobre todo para aquellos con superficie agrícola menor a una hectárea.

Si bien este valor es bajo, es importante indicar que en un estudio similar realizado en México el to credit, distance from the district's capital, access to social programs, perception of sufficiency of their level of income, among others.

In order to determine the characteristics of the groups of producers who receive extension services, the algorithm of the CHAID (Chi-squared Automatic Interaction Detection) classification tree was applied, which is a method of multivariate analysis which through a technique of segmentation analysis of variables (explained and explicative) allows establishing the dependence relationships between them (Escobar, 2007); response trees based on the relative frequencies in their relationships were formed with these variables. As restriction to the system, it was established that the groups have at least $50 \%$ of producers who manage to gain access to services of agricultural extension. For the processing of data, the statistical software IBM Statistics, version 20, was used.

After obtaining the results for the extension services in general, the same analysis was performed for the services of agricultural extension offered by each purveyor institution, whether public or private, with the aim of determining if any of them had a characteristic target population or was focused on some typology of the agriculture and livestock producer.

Cuadro 1. Cobertura de servicios de extensión en el Perú según tamańo de unidad agropecuaria (2012).

Table 1. Coverage of extension services in Peru based on the agricultural and livestock unit size (2012).

\begin{tabular}{lrrr}
$\begin{array}{c}\text { Tamaño de unidad } \\
\text { agropecuaria } \\
\text { (ha) }\end{array}$ & $\begin{array}{c}\text { Productores } \\
\text { asistidos }\end{array}$ & $\begin{array}{c}\text { Total } \\
\text { productores }\end{array}$ & $\begin{array}{c}\text { \% de } \\
\text { Cobertura }\end{array}$ \\
\hline Menos de 1 & 57534 & 961251 & 6.0 \\
De 1 a 2 & 43488 & 489804 & 8.9 \\
De 2 a 3 & 32838 & 274878 & 11.9 \\
De 3 a 5 & 36730 & 233213 & 15.7 \\
De 5 a 10 & 34070 & 166099 & 20.5 \\
De 10 a 20 & 13467 & 58065 & 23.2 \\
De 20 a 50 & 4615 & 19102 & 24.2 \\
De 50 a 100 & 890 & 3494 & 25.5 \\
De 100 a 500 & 440 & 1574 & 28.0 \\
De 500 a 1000 & 54 & 261 & 20.7 \\
Más de 1 000 & 78 & 354 & 22.0 \\
\hline Total & 224204 & 2208095 & 10.2 \\
\hline
\end{tabular}

Fuente: elaboración propia a partir de datos del Censo Nacional Agropecuario (2012). Source: authors' elaboration from data from the National Agricultural and Livestock Census (2012). 
nivel de cobertura de la asistencia técnica y capacitación fue de solo $3 \%$ de un total de más de cuatro millones de unidades productivas analizadas (Cuevas et al., 2012), no existiendo datos similares para otros países de Latinoamérica, de tal manera de poder generalizar la situación de pobre acceso a los servicios de extensión.

En el Cuadro 2 se muestran los servicios de extensión en función de la entidad ofertante, en función de las capacitaciones, asistencia técnica y asesorías realizadas. Los resultados muestran que los servicios se han descentralizado, recayendo la responsabilidad de estos en los gobiernos locales y regionales, situación muy diferente a la observada en el censo de 1993, donde los servicios de extensión de los gobiernos regionales y locales eran nulos.

Esta mayor participación de los gobiernos locales podría ser la oportunidad de potenciar un sistema de extensión agrícola más flexible y contextualizada. Los servicios de extensión descentralizados mejoran la rendición de cuentas a los usuarios locales y facilitan a los clientes la "compra» de los servicios de investigación y productos que respondan mejor a sus necesidades (World Bank, 2012). Sin embargo, para que el trabajo a este nivel sea efectivo deberá fortalecerse el accionar de los técnicos locales.

Es importante señalar que bajo el rubro de sector privado se incluyen los servicios de extensión ofertados por empresas, personas naturales, organismos no gubernamentales y asociaciones de productores, los cuales han venido cubriendo los servicios que han sido dejados de lado por el sector público y que constituyen casi $40 \%$ de la oferta de los servicios.

Cuadro 2. Servicios de extensión en el Perú según entidad ofertante, 2012.

Table 2. Extension services in Peru according to the offering state, 2012.

\begin{tabular}{lcr}
\hline \multicolumn{1}{c}{$\begin{array}{c}\text { Entidad } \\
\text { ofertante }\end{array}$} & $\begin{array}{c}\text { Total de } \\
\text { servicios realizados }\end{array}$ & $\%$ \\
\hline Sector Privado & 101553 & 38.0 \\
Gobierno Nacional & 74263 & 27.8 \\
Gobierno Local & 72186 & 27.0 \\
Gobierno Regional & 19394 & 7.3 \\
\hline Total & 267396 & 100.0 \\
\hline
\end{tabular}

Fuente: elaboración propia a partir de datos del Censo Nacional Agropecuario, (2012). Source: authors' elaboration from data from the National Agricultural and Livestock Census (2012).

\section{Results AND Discussion}

The coverage of extension services in Peru is shown in Table 1, in function of the size of the agricultural/livestock producer. In it, it can be seen that the coverage for the whole country is $10.2 \%$ of the total producers, with a decreasing trend in function of the smaller size of the agricultural and livestock unit, surface; this would be indicating initially that changes in the approach of the services have not managed to have efficacy with regards to the provision of extension services for small-scale farmers, particularly for those with agricultural surface smaller than a hectare.

Although this value is low, it is important to indicate that in a similar study carried out in México, the level of coverage of technical assistance and training was only $3 \%$ of a total of more than four million productive units analyzed (Cuevas et al., 2012), with no similar data available for other countries in Latin America, in order to be able to generalize the situation of poor access to extension services.

In Table 2 the extension services are shown in function of the offering entity, in function of training, technical assistance and consultancies performed. Results show that the services have been decentralized, with the responsibility for these falling on the local and regional governments, a quite different situation from the one observed in the 1993 census, where the extension services of the regional and local governments were non-existent.

This higher participation of local governments could be the opportunity to foster a more flexible and contextualized agricultural extension system. Decentralized extension services improve accountability to the local users and ease for clients the "purchase" of research services and of products that better respond to their needs (World Bank, 2012). However, for the work at this level to be effective, the operation of local technicians should be strengthened.

It is important to point out that under the sphere of the private sector, the extension services offered by companies, individuals, non-governmental organizations, and producers' associations are included, which have been covering the services that have been set aside by the public sector and which constitute almost $40 \%$ of the services offer. 
La posibilidad de que exista una oferta privada de servicios de extensión es importante, pues se constituye con un actor más flexible, lo que no quiere decir que los gobiernos regionales o locales deban dejar de ofrecerlos. Más que optar por uno u otro sector, debe aplicarse un enfoque unificado, que aproveche las sinergias que objetivamente pueden obtenerse estableciendo vínculos de trabajo entre ambos (Sotomayor et al., 2011).

Respecto a los servicios del Gobierno Nacional, una de las mayores dificultades que se observa es que un porcentaje importante se realiza a través de proyectos especiales, es decir, no constituyen un servicio estable. Por otro lado, se ha observado que la oferta de servicios de extensión por parte de las universidades es inexistente.

En el Cuadro 3 se presentan los resultados del análisis del perfil de los productores que sí reciben servicios de extensión. Se puede indicar que las variables que definen el perfil de los productores que reciben servicios de extensión en el Perú son: superficie agrícola, asociacionismo y gestión de créditos. Las otras variables estudiadas (edad y sexo del productor, condición jurídica, nivel de alfabetismo, nivel de educación, uso de maquinaria agrícola, distancia a la capital del distrito, acceso a programas sociales, percepción de la suficiencia de su nivel de ingresos, entre otras) no han mostrado tener una influencia significativa sobre el nivel de cobertura de la extensión, bajo las restricciones del análisis realizado.

$\mathrm{Si}$ analizamos el índice de respuesta acumulado de la prueba se observará que el grupo de productores que accede con mayor facilidad a los servicios de
The possibility for there to be a private offer of extension services is important, for it is constituted with a more flexible actor, which does not mean that the regional or local governments should cease to offer them. Rather than opt for one sector or another, a unified approach should be applied, which can take advantage of the synergies that can be obtained objectively by establishing work relations between each other (Sotomayor et al., 2011).

Concerning the services of the National Government, one of the greatest difficulties observed is that an important percentage is carried out through special projects, that is, they do not constitute a stable service. On the other hand, it has been seen that the offer of extension services by the universities is inexistent.

The results of the profile analysis of the producers who do receive extension services are presented in Table 3. It can be indicated that the variables that define the profile of the producers who receive extension services in Peru are: agricultural surface, associationism, and credit management. The other variables studied (age and sex of the producer, legal condition, level of illiteracy, level of education, use of agricultural machinery, distance to the capital from the district, access to social programs, perception of the sufficiency of their level of income, among others) have not shown to have a significant influence on the level of coverage of the extension, under the restrictions of the analysis performed.

If we analyze the index of response accumulated from the trial, it will be seen that the group of producers who gain access more easily to the

Cuadro 3: Perfiles de productores que reciben servicios de extensión en el Perú.

Table 3: Profiles of producers who receive extension services in Peru.

\begin{tabular}{|c|c|c|c|c|}
\hline Grupos & Descripción & $\begin{array}{l}\text { Tamaño de } \\
\text { grupo }\end{array}$ & $\begin{array}{l}\text { Índice de } \\
\text { respuesta }\end{array}$ & $\begin{array}{l}\text { Índice de respuesta } \\
\text { acumulado }\end{array}$ \\
\hline 1 & $\begin{array}{l}\text { Asociación = "Sî". Superficie agrícola = "De } 10 \text { a } 20 \text { ha", } \\
\text { "Mas de } 10000 \text { ha" } \\
\text { Tramita Préstamo = "Si" }\end{array}$ & 6648 & $54.99 \%$ & $54.99 \%$ \\
\hline 2 & $\begin{array}{l}\text { Asociación = "Sî". Superficie agrícola = "De } 5 \text { a } 10 \text { ha" } \\
\text { Tramita Préstamo = "Sî" }\end{array}$ & 17220 & $49.16 \%$ & $50.78 \%$ \\
\hline 3 & $\begin{array}{l}\text { Asociación = "Sî". Superficie agrícola = "De } 20 \text { a } 30 \text { ha", } \\
\text { "De } 30 \text { a } 40 \text { ha", "De } 40 \text { a } 50 \text { ha", "De } 50 \text { a } 100 \text { ha”, "De } \\
100 \text { a } 200 \text { ha", "De } 200 \text { a } 500 \text { ha" }\end{array}$ & 6428 & $47.82 \%$ & $50.16 \%$ \\
\hline
\end{tabular}

Fuente: elaboración propia a partir de datos del Censo Nacional Agropecuario (2012) \&ource: authors' elaboration from data from the National Agricultural and Livestock Census (2012). 
extensión son aquellos que tienen superficie agrícola de 5 a 500 hectáreas y de 10000 hectáreas a más, que se encuentran asociados y que pueden tramitar créditos.

Todas estas características se encuentran muy vinculadas a las de un agricultor comercial, mostrando con claridad que el enfoque desarrollado no viene siendo eficaz para responder a la demanda por servicios de extensión de la pequeña agricultura, la cual, como hemos señalado anteriormente, constituye el grupo mayoritario en la agricultura peruana. Es importante señalar además la importancia de la asociatividad en el acceso a los servicios de extensión, por lo que es fundamental promoverla.

Los resultados obtenidos nos permiten además corroborar la necesidad de masificar los modelos de extensión focalizados en los pequeños productores; es importante poner en práctica medidas que maximicen la inclusión de los que normalmente se encuentran en desventaja, como los pobres, las mujeres y los pequeños agricultores, y que maximice el impacto positivo en sus medios de vida (Rajalahti et al., 2008).

Estos modelos deberían de incluir diferentes actores, con el fin de responder a la complejidad de sus sistemas de forma más eficaz que los modelos basados en los enfoques vinculados a la agricultura comercial. Por ejemplo, los enfoques basados en la financiación pública que involucran a los gobiernos locales, el sector privado, las organizaciones no gubernamentales y las organizaciones de productores en la prestación de servicios de extensión pueden ser más relevantes para los agricultores de subsistencia, mientras que diversas formas de cofinanciación privada pueden ser apropiadas para la agricultura comercial (World Bank, 2012).

Otros autores afirman la misma necesidad, indicando que la formación de alianzas público-privadas es necesaria para garantizar que la extensión agrícola llegue a todos los agricultores, no solo a los de gran escala, y a los productores comerciales (Al-Sharafat et al., 2012).

$\mathrm{Al}$ evaluar el perfil de los productores en función de la institución de la cual han recibido servicios de extensión se observa que no existe un perfil específico, lo que indica que las instituciones no tienen una acción diferenciada sobre el territorio, situación que reduce la eficiencia del sistema. Esto trae a colación la necesidad de la formación de redes entre las instituciones, de tal manera de que su articulación permita una mayor cobertura y eficiencia en el uso de los recursos. extension services are those that have an agricultural surface of 5 to 500 hectares and of 10000 hectares of more, who are associated and who can negotiate credits.

All of these characteristics are quite connected to those of a commercial farmer, showing with clarity that the approach developed is not effective to respond to the demand for extension services of small-scale agriculture, which, as we have pointed out before, constitutes the majority group in Peru's agriculture. It is important to also point out the importance of associativity in the access to extension services, so it is fundamental to promote it.

The results obtained also allow us to corroborate the need to make the extension models widespread focused on small-scale farmers; it is important to implement practices that maximize the inclusion of those who are normally at a disadvantage, such as the poor, women, and small-scale farmers, and who maximize the positive impact in their livelihoods (Rajalahti et al., 2008).

These models should include different actors, with the aim of responding to the complexity of their systems in a more efficient way than the models based on the approaches linked to commercial agriculture. For example, the approaches based on public funding that involve the local governments, the private sector, non-governmental organizations, and producers' organizations in the provision of extension services can be more relevant for subsistence farmers, while various forms of private co-funding can be appropriate for commercial agriculture (World Bank, 2012).

Other authors state the same need, indicating that the formation of public-private alliances is necessary to guarantee for agricultural extension to reach all the farmers, not only large-scale and commercial producers (Al-Sharafat et al., 2012).

When evaluating the producers' profile in function of the institution from which they have received extension services, it is observed that there is not a specific profile, which indicates that the institutions do not have a differentiated action on the territory, situation that reduces the efficiency of the system. This brings up the need of forming networks between institutions, so that their articulation can allow a greater coverage and efficiency in the use of the resources.

As can be seen, these results show the need to establish diversified approaches in order to reach 
Como se puede observar, en estos resultados se muestra la necesidad de establecer enfoques diversificados para alcanzar a las diferentes tipologías de productores, como indica Aguirre (2012), las diferencias entre países y situaciones conllevan a que no puedan aplicarse modelos únicos de extensión desarrollados bajo condiciones diferentes, aun dentro de un mismo país.

\section{ConClusiones}

Los resultados de la investigación muestran que los cambios suscitados en los enfoques de extensión en el Perú no han logrado mejorar el acceso a los mismos a nivel de los pequeños productores verificándose, sin embargo, que la participación de los gobiernos locales y del sector privado en estas actividades es bastante importante. Por otro lado, la relación que existe entre la cobertura de los servicios de extensión y factores como el tamaño productivo, el asociacionismo y el acceso a créditos, muestra claramente que los nuevos enfoques logran alcanzar principalmente a los productores comerciales que se encuentran asociados, lo que demuestra la importancia de la promoción de la asociatividad agraria y de buscar nuevos enfoques para alcanzar a los pequeños productores.

Se vuelve necesaria la puesta en marcha de un sistema de innovación descentralizado y articulado, con diferentes enfoques en relación a las diferentes realidades y perfiles de productores, un sistema que fortalezca los intentos de los gobiernos locales, regionales y del sector privado.

\section{Literatura Citada}

Aguirre, Francisco. 2012. El nuevo impulso de la extensión rural en América Latina: Situación actual y perspectivas, Santiago de Chile: RELASER. 53 p.

Alemany, Carlos. 2008. Volvió la extensión... iy se armó la discusión! In: Thornton, Ricardo y Gustavo Cimadevilla (eds). Grises de la extensión, la comunicación y el desarrollo. Buenos Aires. Instituto Nacional de Tecnología Agropecuaria (INTA). pp: 27-50.

Al-Sharafat, Ali, Mohammad Altarawneh, and Ebraheem Altahat. Effectiveness of agricultural extension activities. 2012. American Journal of Agricultural and Biological Sciences. Vol. 7, Num. 2.

Birbaumer, Georg. 2011. Extensión, comunicación y desarrollo rural. Asunción: Deutsche Gesellschaft fuer Internationale Zusammenarbeit (GIZ). 277 p.

Carrasco, Alfredo. 1990. Evaluación y propuesta de un sistema de extensión agropecuaria. Lima: Ministerio de Agricultura del Perú. 117 p.

Cuevas, Venancio, Julio Baca, Fernando Cervantes, y José Aguilar. 2012. Asistencia técnica en el sector agropecuario the different typologies of producers; as Aguirre (2012) indicates the differences between countries and situations imply that unique extension models developed under different conditions cannot be implemented, even within the same country.

\section{Conclusions}

The results of the study show that the changes brought about in the extension approaches in Peru have not managed to improve access to these at the level of small-scale producers, however this verifies that the participation of local governments and the private sector in these activities is rather important. On the other hand, the relationship there is between the coverage of extension services and factors like the productive size, associationism, and access to credits, clearly shows that the new approaches manage to reach primarily the commercial producers who are associated, which proves the importance of the promotion of agrarian associativity and of seeking new approaches to reach small-scale producers.

The implementation of a decentralized and articulated innovation system becomes necessary, with different approaches in relation to the different realities and profiles of producers, a system that strengthens the efforts of local and regional governments, and the private sector.

$$
\text { - End of the English version - }
$$

en México: análisis del VIII censo agropecuario y forestal. Revista Mexicana de Ciencias Agrícolas. Vol. 3, Num. 5.

Dethier, Jean-Jacques, and Alexandra Effenberger. 2012. Agriculture and development: A brief review of the literature. Economic Systems. Vol. 36, Num. 2.

Eguren, Fernando. 2006. La reforma agraria y el desarrollo rural en la región andina. Lima. CEPES. 335 p.

Escobar, Mercado. 2007. El análisis de segmentación: Técnicas y aplicaciones de los árboles de clasificación. Colección cuadernos metodológicos. Madrid. Centro de Investigaciones Sociológicas (CIS). 239 p.

Feder Gershon, Anderson, R. Jock, Regina Birner, and Klaus Deininger. 2010. Promises and realities of community-based agricultural extension, Washington DC: IFPRI. 23 p.

Hellin, Jon. 2012. Agricultural extension, collective action and innovation systems: Lessons on network brokering from Peru and Mexico. Journal of Agricultural Education and Extension. Vol. 18, Num. 2.

Hellin, Jon, and John Dixon. 2008. Operationalising participatory research and farmer-to-farmer extension: the Kamayoq in Peru. Development in Practice. Vol. 18, Num 4. 
Ho, Raúl, y Roberto Montero. 2014. Extensión rural y asistencia técnica en el sector campesino: Experiencias del periodo 1997-2013. Lecciones aprendidas, Lima: Soluciones Prácticas. $101 \mathrm{p}$.

Hu, Ruifa, Yaqing Cai, Kevin Z. Chen, and Jikun Huang. 2012. Effects of inclusive public agricultural extension service: Results from a policy reform experiment in western China. China Economic Review. Vol. 23, Num. 4.

Instituto Nacional de Estadística e Informática. I2013. V censo nacional agropecuario. REDATAM. Sistema de consulta de datos, Versión 1.0. In: http://censos.inei.gob.pe/Cenagro/ redatam.

Instituto Nacional de Estadística e Informática. 1994. III censo nacional agropecuario. Sistema de consulta de resultados censales. In: http://censos.inei.gob.pe/bcoCuadros/IIIcenagro.htm.

Kidd, Andrew, John Lamers, Pier Ficarelli, and Volker Hoffmann. 2000. Privatising agricultural extension: caveat emptor. Journal of Rural Studies. Vol. 16, Num. 1.

Labarthe, Pierre, and Catherine Laurent. 2013. Privatization of agricultural extension services in EU: Towards a lack of adecuate knowledge for small-scale farms? Food Policy 38. Vol. 38.

McMahon, Matthew, y Alberto Valdés. 2011. Análisis del extensionismo agrícola en México. París. Organización para la cooperación y el desarrollo económicos. 73 p.

Mora, Jorge. 2002. Desarrollo rural, cambio Institucional y extensión rural en Centroamérica y México. San José de Costa Rica. Instituto Interamericano de Cooperación para la Agricultura (IICA). 59 p.

Ortiz, Oscar. 2006. Evolution of agricultural extension and information dissemination in Peru: An historical perspective focusing on potato-related pest control. Agriculture and $\mathrm{Hu}-$ man Values. Vol. 23, Num. 4.
Pye-Smith, Charlie. 2012. Agricultural extension: A time for change. Nairobi. Technical Centre for Agricultural and Rural Cooperation (CTA). 30 p.

Rajalahti, Rilkka, Willem Janssen, and Eija Pehu. 2008. Agricultural Innovation Systems: From diagnostics toward operational practices. Discussion Paper 38. Washington. World Bank. 87 p.

Ramirez, Javier, y Gastón Roe. 2007. Proyecto Quo Vadis: El futuro de la innovación tecnológica agraria en el Perú. Lima. Tarea Gráfica Educativa. 328 p.

Remy, María Isabel, y Carlos De los Ríos. 2012. El caso de Perú. In: Soto, Fernando y Sergio Gómez (eds). Dinámicas en el mercado de la tierra en América Latina y el Caribe: Concentración y extranjerización. Santiago de Chile. Oficina Regional del Fondo de las Naciones Unidas para la Agricultura y la Alimentación (FAO). pp. 435 - 466.

Sotomayor, Octavio, Adrián Rodríguez, y Mónica Rodrigues. 2011. Competitividad, sostenibilidad e inclusión social en la agricultura. Nuevas direcciones en el diseño de políticas en América Latina. Santiago de Chile. CEPAL. 345 p.

Swanson, Burton. 2010. Estudio mundial sobre buenas prácticas de los servicios de extensión y asesoramiento agropecuarios en el mundo. Roma. Fondo de las Naciones Unidas para la Agricultura y la Alimentación (FAO). 72 p.

Van den Ban, Anne, and Ranajit Samanta. 2006. Agricultural extension in asian nations: Why it needs change! In: Van den Ban, Anne and Ranajit Samanta (eds). Changing roles of agricultural extension in asian nations. Nueva Delhi. B. R. Publishing Corporation. pp: 1-22.

Wiener, Hugo. 2010. Promoviendo el mercado de servicios de extensión agraria en el Perú. Lima: Supergráfica S.R.L. 110 p.

World Bank. 2012. Agricultural innovation systems: An investment sourcebook. Washington DC. World Bank. 658 p. 